\title{
Studi Deskriptif Infeksi HIV pada Anak di Rumah Sakit Umum Pusat Adam Malik Medan
}

Evalina $R$

Departemen Ilmu Kesehatan Anak, Fakultas Kedokteran Universitas Sumatera Utara, Rumah Sakit Umum Pusat Adam Malik, Medan

Latar belakang. Anak mendapat infeksi HIV terutama akibat transmisi selama dalam kandungan, saat persalinan, dan saat mendapat air susu ibu. Bayi dan anak yang terinfeksi HIV kemungkinan akan berkembang menjadi acquired immunodeficiency syndrome (AIDS) atau akan tetap asimtomatis sampai beberapa tahun sebelum terjadi infeksi oportunistik.

Tujuan. Menilai profil infeksi HIV di Departemen Ilmu Kesehatan Anak, Fakultas Kedokteran Universitas Sumatera Utara, Rumah Sakit Umum Pusat Adam Malik, Medan.

Metode. Penelitian deskriptif retrospektif terhadap semua anak dengan infeksi HIV antara tahun 2006 sampai 2010. Diagnosis ditegakkan berdasarkan anamnesis, pemeriksaan fisik, dan pemeriksaan laboratorium.

Hasil. Selama periode 5 tahun didapatkan 53 anak dengan diagnosis infeksi HIV (35 laki-laki dan 18 perempuan), 46 (86,8\%) lahir secara spontan dan 7 (13,2\%) dengan seksio sesaria. Dari riwayat pemberian makan saat bayi, Asi dan formula diberikan kepada 41 (77,4\%) anak dan 12 (22,6\%) anak hanya mendapat susu formula. Supresi imun berat terdapat pada $38(71,7 \%)$ anak, supresi imun sedang pada $8(15,1 \%)$, supresi imun ringan pada $2(3,8 \%)$ anak dan $5(9,4 \%)$ anak tanpa supresi imun. Malnutrisi berat ditemukan pada $30(56,6 \%)$ anak, $16(30,1 \%)$ malnutrisi sedang, dan 7 (13,2\%) anak gizi normal. Gambaran klinis adalah malnutrisi berat pada 30 (56,6\%) anak, kandidiasis mulut 18 (34\%) anak dan diikuti dengan diare berkepanjangan 14 (26,4\%) anak dan tuberkulosis pada 13 (24,5\%) anak. Empat puluh lima (84,9\%) anak memiliki kedua orang tua positif terinfeksi HIV, $6(11,3 \%)$ anak hanya ibu yang positif HIV, dan $2(3,8 \%)$ anak kedua orang tuanya tidak terinfeksi HIV (satu anak adopsi dan satu lagi ada riwayat transfusi). Tiga puluh tujuh $(69,8 \%)$ anak sudah mendapat terapi antiretroviral (ART), 8 (15,2\%) anak belum terindikasi ART, dan $8(15,2 \%)$ anak hilang dari pemantauan. Tiga puluh sembilan $(73,6 \%)$ anak masih hidup, 6 $(11,3 \%)$ anak sudah meninggal, dan 8 (15,1\%) anak tidak diketahui.

Kesimpulan. Anak dengan infeksi HIV mayoritas lahir secara spontan, mendapat ASI campur susu formula dan mengalami malnutrisi berat serta supresi imun berat saat diagnosis ditegakkan.

Sari Pediatri 2012;14(2):73-8.

Kata kunci: HIV, supresi imun, anak

\footnotetext{
Alamat korespondensi:

Dr. Evalina R, Sp.A, Departemen Ilmu Kesehatan Anak Fakultas Kedokteran Universitas Sumatera Utara/ RSUP H.Adam Malik Jl. Bunga Lau no.17 Medan. Telp (061) 8361721 - 8365663. Fax. (061) 8361721 E-mail: ritaerusli@yahoo.co.id; kotak Pos697 Medan - 20136.
}

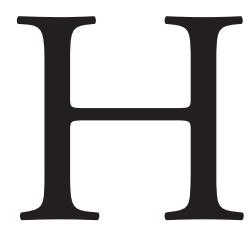

ampir semua anak yang terinfeksi human immunodeficiency virus (HIV) mendapatkannya selama dalam kandungan, saat proses kelahiran, dan melalui air susu ibu. Semakin banyak 
jumlah wanita yang terifeksi HIV berakibat meningkatnya jumlah anak yang tertular HIV. ${ }^{1-2}$ Penggunaan obat anti retrovirus untuk pencegahan transmisi HIV dari ibu ke anak menghasilkan penurunan angka transmisi yang dramatis pada bayi sampai dibawah $2 \%$ di beberapa negara dan mengakibatkan angka anak dengan infeksi HIV menjadi sangat menurun. ${ }^{3-5}$

Apabila seorang bayi terlahir dari ibu dengan HIV positif, idealnya dokter spesialis anak bertemu dengan ibu tersebut sebelum bayi lahir untuk mendiskusikan mengenai penanganan bayi selanjutnya salah satunya adalah mengenai pemberian makanan. ${ }^{6-7}$ Bayi dan anak yang terinfeksi HIV mungkin akan berkembang menjadi AIDS atau asimptomatis untuk beberapa tahun sebelum berkembang menjadi infeksi oportunistik. Bayi yang terinfeksi HIV secara vertikal, AIDS dapat berkembang dengan cepat pada bulan-bulan awal dari kehidupannya berupa gagal tumbuh, malnutrisi berat, diare, kandidiasis oral yang persisten atau rekuren atau dengan pneumonia pneumocystis jiroveci. ${ }^{8}$

Tata laksana utama adalah dengan pengawasan yang ketat dan multidisiplin berupa pencegahan terhadap infeksi berupa profilaksis dan vaksinasi, pengobatan secepatnya terhadap infeksi oportunistik dan dukungan nutrisi untuk mencegah gagal tumbuh serta pemberian terapi anti retroviral. ${ }^{9}$

\section{Metode}

Penelitian studi deskriptif. Data diperoleh dari rekam medis pasien Poliklinik Alergi Imunologi Departemen Ilmu Kesehatan Anak Fakultas Kedokteran Universitas Sumatera Utara, Rumah Sakit Umum Pusat Adam Malik, Medan dengan diagnosis infeksi HIV dari Januari 2006 sampai September 2010. Diagnosis ditegakkan berdasarkan gambaran klinis sesuai klasifikasi WHO. ${ }^{18}$

\section{Stadium klinis WHO}

\section{Stadium klinis 1}

- Asimtomatik

- Limfadenopati generalisata persisten

\section{Stadium klinis 2}

- Hepatosplenomegali persisten yang tidak dapat dijelaskan
- Erupsi pruritik papular

- Infeksi virus wart luas

- Angular cheilitis

- Moluskum kontagiosum luas

- Ulserasi oral berulang

- Pembesaran kelenjar parotis persisten yang tidak dapat dijelaskan

- Eritema ginggival lineal

- Herpes zoster

- Infeksi saluran napas atas kronik atau berulang (otitis media, otorrhoea, sinusitis, tonsillitis )

- Infeksi kuku oleh fungus

\section{Stadium klinis 3}

- Malnutrisi sedang yang tidak dapat dijelaskan, tidak berespons secara adekuat terhadap terapi standar

- Diare persisten yang tidak dapat dijelaskan (14 hari atau lebih )

- Demam persisten yang tidak dapat dijelaskan (lebih dari $37,5^{\circ} \mathrm{C}$ intermiten atau konstan, $>1$ bulan)

- Kandidosis oral persisten (di luar saat 6-8 minggu pertama kehidupan)

- Oral hairy leukoplakia

- Periodontitis/ginggivitis ulseratif nekrotikans akut

- TB kelenjar

- TB Paru

- Pneumonia bakterial yang berat dan berulang

- Pneumonistis interstitial limfoid simtomatik

- Penyakit paru-berhubungan dengan HIV yang kronik termasuk bronkiektasis

- Anemia yang tidak dapat dijelaskan $(<8 \mathrm{~g} / \mathrm{dl})$, neutropenia $\left(<500 / \mathrm{mm}^{3}\right)$ atau trombositopenia $\left(<50000 / \mathrm{mm}^{3}\right)$

\section{Stadium klinis 4}

- Malnutrisi, wasting, dan stunting berat yang tidak dapat dijelaskan dan tidak berespons terhadap terapi standar

- Pneumonia pneumosistis

- Infeksi bakterial berat yang berulang (misalnya empiema, piomiositis, infeksi tulang dan sendi, meningitis, kecuali pneumonia)

- Infeksi herpes simplex kronik (orolabial atau kutaneus $>1$ bulan atau viseralis di lokasi manapun)

- TB ekstrapulmonar

- Sarkoma Kaposi 
- Kandidiasis esofagus (atau trakea, bronkus, atau paru)

- Toksoplasmosis susunan saraf pusat (di luar masa neonatus)

- Ensefalopati HIV

- Infeksi sitomegalovirus (CMV), retinitis atau infeksi CMV pada organ lain, dengan onset umur $>1$ bulan

- Kriptokokosis ekstrapulmonar termasuk meningitis

- Mikosis endemik diseminata (histoplasmosis, coccidiomycosis)

- Kriptosporidiosis kronik (dengan diarea)

- Isosporiasis kronik

- Infeksi mikobakteria non-tuberkulosis diseminata

- Kardiomiopati atau nefropati yang dihubungkan dengan HIV yang simtomatik

- Limfoma sel B non-Hodgkin atau limfoma serebral

- Progressive multifocal leukoencephalopathy

Selain berdasarkan kriteria klinis dilakukan juga penilaian laboratorium, yaitu pemeriksaan antibodi HIV untuk anak usia diatas 18 bulan dan dengan pemeriksaan virologi HIV berupa PCR RNA (viral load) untuk anak berusia kurang dari 18 bulan. Tanda yang mengarahkan kemungkinan infeksi HIV adalah infeksi oportunistik, yaitu infeksi dengan kuman, parasit, jamur atau protozoa, yang lazim tidak menyebabkan penyakit pada anak normal. Karena gangguan fungsi imun, terutama imunitas selular, maka anak akan menjadi sakit apabila terpajan pada organisme tersebut, lebih lama, lebih berat, serta sering berulang. ${ }^{10-15}$

Data dasar yang dikumpulkan adalah umur, jenis kelamin, urutan kelahiran, cara persalinan, faktor risiko dari orang tua, dan usia saat diagnosis HIV ditegakkan. Dicatat juga cara pemberian makan yaitu apakah si anak sejak lahir mendapat ASI (air susu ibu) ekslusif, susu formula ataukah campuran ASI dan susu formula. Gejala klinis saat pertama kali datang, infeksi oportunistik, dan tingkat supresi imun yang terdapat pada subyek juga dicatat.

\section{Hasil}

Penelitian berlangsung selama 5 tahun yaitu dari Januari 2006 sampai dengan September 2010.
Terdapat 53 anak dengan diagnosis infeksi HIV, terdiri dari 35 anak laki-laki (66\%) dan 18 anak perempuan (34\%). Berdasarkan riwayat orang tua, 45 (84,9\%) anak memiliki kedua orang tua dengan positif terinfeksi HIV, $6(11,3 \%)$ anak ibu yang positif terinfeksi HIV dan 2 anak $(3,8 \%)$ kedua orang tua yang tidak terinfeksi HIV (satu anak adalah anak adopsi dan satu anak memiliki riwayat transfusi darah 5 tahun yang lalu).

Dari 53 anak, 46 anak (86,8\%) lahir secara pervaginam dan 7 anak lahir secara seksio sesaria $(13,2 \%)$. Diagnosis infeksi HIV ditegakkan saat anak usia $0-11$ bulan 8 orang $(15,1 \%), 12-35$ bulan 17 orang (32,1\%), 36-59 bulan 13 orang $(24,5 \%)$ dan pada usia $\geq 5$ tahun 15 orang $(28,3 \%)$. Cara pemberian makan sejak lahir yaitu makanan campuran air susu ibu (ASI) dan susu formula diberikan kepada $41(77,4 \%)$ anak dan $12(22,6 \%)$ anak mendapatkan susu formula. Tidak terdapat anak pada subyek penelitian kami yang mendapat ASI eksklusif. Malnutrisi berat terdapat pada $30(56,6 \%)$ anak, $16(30,2 \%)$ anak dengan malnutrisi sedang, dan $7(13,2 \%)$ anak tanpa malnutrisi. Karakteristik subyek penelitian tertera pada Tabel 1 .

Tabel 1. Karakteristik subyek penelitian

\begin{tabular}{ll}
\hline Karakteristik subyek & Total (\%) \\
\hline Jenis kelamin & \\
Laki-laki & $35(66)$ \\
$\quad$ Perempuan & $18(34)$ \\
Riwayat infeksi HIV orang tua & \\
$\quad$ Ayah dan ibu & $45(84,9)$ \\
$\quad$ Hanya ibu & $6(11,3)$ \\
$\quad$ Ayah dan ibu tidak terinfeksi & $2(3,8)$ \\
Cara kelahiran & \\
$\quad$ Per vaginam & $46(86,8)$ \\
Seksio cesaria & $7(13,2)$ \\
Usia saat terdiagnosis (bulan) & \\
0-11 & $8(15,1)$ \\
12-35 & $17(32,1)$ \\
$\quad 36-59$ & $13(24,5)$ \\
$\quad \geq 5$ & $15(28,3)$ \\
Jenis makanan & \\
$\quad$ Asi + susu formula & $41(77,4)$ \\
Susu formula & $12(22,6)$ \\
Status nutrisi saat terdiagnosis & \\
$\quad$ Malnutrisi berat & $30(56,6)$ \\
Malnutrisi sedang & $16(30,2)$ \\
Normal & $7(13,2)$ \\
\hline
\end{tabular}


Dari 53 anak, secara klinis saat pertama kali datang adalah malnutrisi berat $30(56,6 \%)$ anak, jamur di mulut 18 (34\%) anak, diare berkepanjangan $14(26,4 \%)$ anak, dan tuberkulosis paru 13 (24,5\%) anak. Berdasarkan supresi sistem imun, supresi imun berat $38(71,7 \%)$ anak, supresi imun sedang $8(15,1 \%)$ anak, supresi imun ringan $2(3,8 \%)$ anak, dan $5(9,4 \%)$ anak tanpa mengalami supresi imun.

Tiga puluh tujuh anak $(69,8 \%)$ saat ini sudah mendapatkan ARV, 8 (15,1\%) anak belum terindikasi untuk mendapatkan ARV, dan 8 (15,1\%) anak hilang dari pemantauan. Sampai tulisan ini dibuat, $39(73,6 \%)$ anak masih hidup, $6(11,3 \%)$ anak meninggal, dan $8(15,1 \%)$ anak tidak diketahui keberadaannya. Kondisi pasien secara keseluruhan tertera pada Gambar 1.

\section{Pembahasan}

Virus ini pertama kali ditemukan oleh Montagnier dari Perancis pada tahun 1983 dan oleh Gallo dari Amerika pada tahun 1984. Infeksi HIV/AIDS (Human Immunodeficiency Virus/Acquired Immune Deficiency Syndrome) pertama kali dilaporkan di Amerika pada tahun 1981 pada orang dewasa homoseksual. Pada anak
AIDS pertama kali dilaporkan oleh Oleske, Rubinstein, dan Amman pada tahun 1983 di Amerika Serikat. ${ }^{16-17}$

Diagnosis HIV pada anak didasarkan pada anamnesis pajanan HIV, gejala klinis yang mencurigakan, dan dipastikan dengan pemeriksaan laboratorium penunjang. Pemeriksaan polymerase chain reaction (PCR) HIV DNA, dan RNA dengan sensitivitas 99\% dan spesifisitas 98\% digunakan untuk menegakkan diagnosis pada anak yang terpapar HIV pada 18 bulan pertama kehidupan. ${ }^{8,17}$

Manifestasi klinis infeksi HIV pada anak bervariasi dari asimptomatis sampai penyakit berat yang dinamakan Acquired Immunodeficiency Syndrome (AIDS). Butir poin penting anamnesis dan gejala klinis yang dapat mengarah kediagnosis HIV dapat didasarkan pada berbagai penyakit yang terangkum dalam Integral Management of Childhood Illness (IMCI) dari WHO, di antaranya pneumonia, malnutrisi dan diare melanjut atau kronik. Pada anak, infeksi HIVterutama terjadi pada usia dini karena sebagian besar (lebih dari 80\%) infeksi HIV pada anak adalah akibat transmisi vertikal dari ibu ke anak. ${ }^{11}$ Pada penelitian kami, diagnosis HIV ditegakkan berdasarkan gejala klinis, mayoritas anak datang pertama kali adalah dengan keluhan malnutrisi, jamur dimulut, diare kronis, dan tuberkulosis paru.

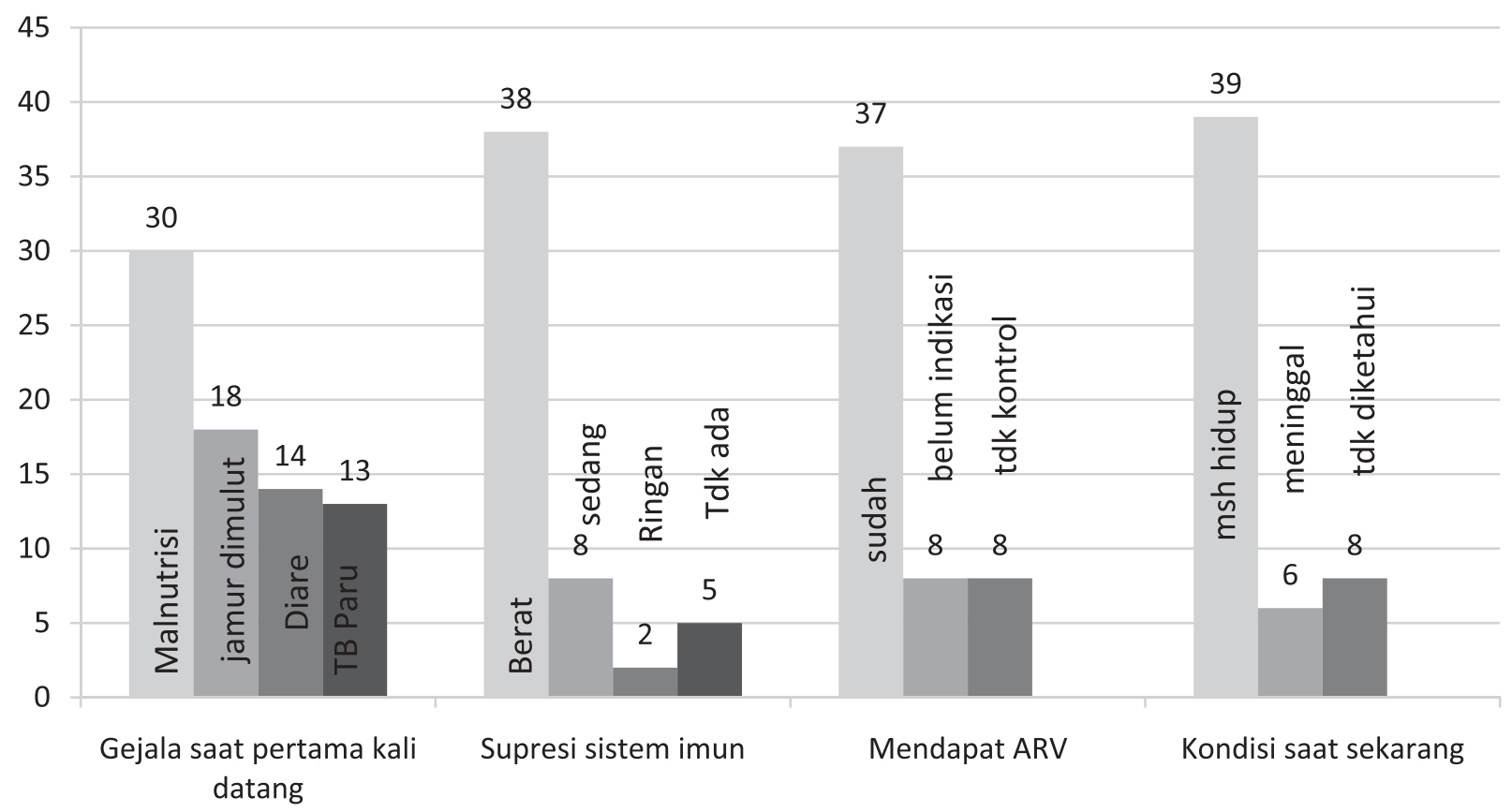

Gambar 1. Kondisi Klinis dan prognosis 
Sembilan dari sepuluh anak yang terinfeksi oleh HIV mendapatkannya dari ibu selama proses kehamilan, proses kelahiran, dan air susu ibu selama proses menyusui. ${ }^{18}$ Penelitian kami mendapatkan hasil $45(84,91 \%)$ anak memiliki kedua orang tua yang positif terinfeksi HIV, 6 (11,32\%) anak ibu yang positif terinfeksi HIV, dan $2(3,77 \%)$ anak kedua orang tua negatif terinfeksi HIV dan setelah ditelusuri salah seorang dari anak tersebut adalah anak adopsi dan seorang lagi terdapat riwayat transfusi darah 5 tahun yang lalu dengan alasan transfusi karena anemia.

Untuk mencegah transmisi HIV dari ibu ke anak yang dikandungnya, obat antiretroviral (ARV) diberikan kepada ibu sebelum lahir dan selama bersalin, untuk bayinya sesudah lahir dan memberikan makanan bayi yang aman sangat direkomendasikan. ${ }^{19}$ Kelahiran dari ibu penderita HIV sebaiknya per abdominam karena walaupun viral load tidak terdeteksi tapi ternyata masih dapat dijumpai virus diserviks maupun vagina. ${ }^{20}$ Dari 53 subyek penelitian kami, 86,7\% lahir secara pervaginam dan mayoritas mendapatkan makanan campuran (ASI dan susu formula). Salah satu faktor risiko terjadinya transmisi adalah pemberian ASI atau mixed feeding (pemberian ASI dan susu formula bersama-sama). ${ }^{21}$

Pada penelitian kami pemeriksaan assay antibody digunakan untuk mendeteksi antibodi terhadap HIV, dan menjadi dasar penegakan diagnosis HIV pada anak umur lebih dari 18 bulan. Sementara pada anak usia kurang dari 18 bulan diperlukan uji diagnostik laboratorik yang mampu mendeteksi virus atau komponennya (PCR atau kultur) ${ }^{10}$ Pemeriksaan laboratorium lain bersifat melengkapi informasi dan membantu dalam penentuan stadium serta pemilihan obat ARV.

Jumlah limfosit CD4 menurun dan CD8 meningkat sehingga rasio CD4/CD8 menurun. Parameter imunologis digunakan bersamaan dengan penilaian klinis sebagai dasar pertimbangan untuk memulai pemberian ARV. Untuk anak usia dibawah 5 tahun penilaian imunologis menggunakan persentase CD4, untuk anak diatas 5 tahun dapat menggunakan nilai absolut CD4. Jumlah absolut atau persentase CD4 dipakai untuk menilai penekanan sistem imun dan sebagai parameter untuk memulai pemberian ARV pada anak yang terinfeksi HIV. ${ }^{10,22}$ Berdasarkan supresi sistem imun pada subyek, mayoritas anak $(71,7 \%)$ datang dalam keadaan supresi imun berat, dan hanya 9,4\% tanpa mengalami supresi imun. Tata laksana infeksi HIV pada anak berdasarkan rekomendasi WHO 2010, untuk anak usia dibawah 2 tahun ARV segera diberikan tanpa melihat jumlah CD4, dan pada anak usia antara 2 sampai 5 tahun ARV diberikan apabila nilai CD4 absolut $<750 \mathrm{sel} / \mathrm{mm}^{3}$ atau persentase CD $4<25 \%$. Bila usia anak diatas 5 tahun, ARV diberikan kalau CD4 absolut $<350 \mathrm{sel} / \mathrm{mm}^{3}{ }^{3}{ }^{23}$

Infeksi HIV berkembang sangat cepat pada bayi dan anak, apabila tanpa terapi. sepertiga dari anak dengan HIV akan meninggal karena AIDS sebelum berusia 1 tahun, dan setengahnya sebelum berusia 2 tahun. ${ }^{23}$ Tanda yang mengarahkan kemungkinan infeksi HIV adalah infeksi oportunistik, yaitu infeksi dengan kuman, parasit, jamur atau protozoa, yang lazimnya tidak menyebabkan penyakit pada anak normal. Karena gangguan fungsi imun, terutama imunitas selular, maka anak akan menjadi sakit apabila terpajan pada organisme tersebut, lebih lama, lebih berat, serta sering berulang. Anak juga akan sering menderita diare berulang. ${ }^{10-12}$

Penanganan bayi yang lahir dari ibu HIV positif dimulai dengan perawatan bayi baru lahir dengan menerapkan kewaspadaan universal, pemberian ARV kepada bayi, pemilihan nutrisi, imunisasi, pencegahan infeksi oportunistik, pemantauan tumbuh kembang, dan penetuan status HIV bayi. Bayi yang terlahir dari ibu HIV positif, statusnya harus diketahui sesegera mungkin setelah lahir. ${ }^{22}$

Setelah seorang anak yang sudah indikasi untuk mendapatkan ART, perlu dipastikan dan diperhatikan kepatuhan jangka panjang dan respons yang baik terhadap ART. Pemantauan yang perlu dilakukan adalah evaluasi klinis, berat badan, dan tinggi badan, perhitungan dosis ART, obat lain yang diberikan bersamaan dan kepatuhan minum obat. ${ }^{24}$ Pada subyek penelitian kami terdapat 8 anak yang tidak kontrol dan tidak diketahui keberadaannya saat ini.

\section{Kesimpulan}

Anak positif HIV sebagian besar mendapatkan infeksi dari ibunya selama dalam kandungan, selama proses kelahiran, dan selama proses menyusui. Dengan pemberian ART diharapkan replikasi virus pada anak dapat dihambat dan anak hidup normal seperti anak lainnya. 


\section{Daftar pustaka}

1. Thisyakorn U. Epidemiology and clinical problems of AIDS in children in South East Asia. MDVI1996;23:8s10 s.

2. UNAIDS report on the global AIDS epidemic: Executive summary/UNAIDS, 2009.

3. Thisyakorn U. Slow progression of human immunodeficiency infection in a 14-year-old boy born to an HIVinfected mother. JPID 2007; 2:105-8.

4. US Department of human health and Services. Guidelines of HIV infection. Didapat dari: http://AIDSinfo.nih. gov/guidelines/.

5. British HIV Association (BHIVA). Guidelines on the management of HIV infection. Didapat dari: http://www. bhiva.org/.

6. Thisyakorn U. Breast feeding and perinatal HIV transmission in Thailand. SCN News 1998; 17:10.

7. Chansinghakul D, Soongsawang K, Pancharoen C, Thaithumyanon P, Limpongsanurak S, Thisyakorn U. Prevention of mother-to-child HIV transmission: MTCTplus initiative program. Accepted for publication in JPID.

8. Pizzo PA, Wilfert CM. Pediatrics AIDS: the challenge of HIV infection in infants, children and adolescents. Edisi ke-3. Baltimore: Williams \& Wilkins; 1994.

9. Thisyakorn U. Pediatrics AIDS. PKB HIV 2009.h.713.

10. Matondang CS, Kurniati N. Infeksi HIV pada bayi dan anak. Dalam: Akib AAP, Munasir Z, Kurniati N. Buku ajar alergi-imunologi anak. Edisi ke-2. Jakarta: Balai Penerbit IDAI; 2007.h.379-416.

11. Boogs JM. Human immunodeficiency virus disease and related opportunistic infection. Dalam: Adelman CD, Casale TB, Corren J. Manual of allergy and immunology. Edisi ke-4. Philadelphia: Lippincot William \& Wilkins; 2002.h.418-39.

12. Mcfarland EJ. Human immunodeficiency virus (HIV) infection. Dalam: Hay WW, Hayward AR, Levin MJ, Sondheimer JM, penyunting. Current pediatric diagnosis and treatment. Edisi ke-16. Colorado: The McGrawHill; 2003.h.1140-9.
13. Paul ME, Shearer WT. Pediatric human immunodeficiency virus infection. Dalam: Leung DYM, Sampson HA, Geha RS, Szefler SJ, penyunting. Pediatric allergy principles and practice. Missouri: Mosby; 2003.h.110-7.

14. Yogev R, Chadwick EG, Acquired immunodeficiency syndrome (human immunodeficiency virus). Dalam: Behrman RE, Kliegman RM, Jenson HB. Textbook of pediatrics. Edisi ke-17. Philadelphia: W.B Saunders; 1998.h.1109-21.

15. WHO. Recommendations on the diagnosis of HIV infection in infantsand children. Geneva; 2010.

16. Abrams E, Moon RY, Robinson LG, van Dyke RB. Routine pediatric care. Dalam: Reads JS, Zeichner SL, penyunting. Handbook of pediatric HIV care. Cambridge: Cambridge University Press; 2006.h.13476.

17. Roitt I, Brostoff J, Male D. Immunology. Edisi ke-6. London: Mosby; 2001.h.317-9.

18. UNAIDS. 'UNAIDS report on the global AIDS epidemic'. Geneva; 2010.

19. WHO/UNAIDS/UNICEF. 'Towards Universal Access: Scaling up priority HIV/AIDS interventions in the health sector'. Geneva; 2010.

20. Kovacs A, Wasserman SS, Burns D, Wright DJ, Cohn J, Landay A, dkk. Determinants of HIV-1 shedding in the genital tract of woman. Lancet 2001;358:1593-601.

21. Read JS. Prevention of mother-to-child transmission of HIV. Dalam: Read JS, Zeichner SL, penyunting. Handbook of pediatric HIV care. Cambridge: Cambridge University Press; 2006.h.107-33.

22. World Health Organization. Antiretroviral therapy for HIV infection in infants and children: toward universal access: recommendation for a public health approach. Geneva: WHO press 2010 revision.

23. Newell M. 'Mortality of infected and uninfected infants born to HIV-infected mothers in Africa: a pooled analysis', Lancet 2004;364:94-41.

24. Departemen kesehatan RI. Pedoman tatalaksana infeksi HIV dan terapi antiretroviral pada anak di Indonesia. Dalam: Kurniati N, penyunting. Jakarta: DepKes RI, 2008. 